\title{
Ovine placental lactogen in the cotyledonary and intercotyledonary placenta of the ewe
}

\author{
W. B. Watkins and S. Reddy \\ Postgraduate School of Obstetrics and Gynaecology, University of Auckland, Auckland, \\ New Zealand
}

\begin{abstract}
Summary. Antibodies raised against purified ovine placental lactogen were used to demonstrate the cellular localization of the hormone in tissues of the ewe placenta and chorionic membranes by immunofluorescence and immunoperoxidase techniques. Although binucleate cells have been shown to appear as early as Day 16 of pregnancy, ovine placental lactogen was not detected in the trophoblast until Day 22 , and in substantial numbers of cells until Day 80 , of gestation. In the more mature placenta, lactogen-immunoreactive material was demonstrated in (a) binucleate cells of the fetal trophoblast, (b) uninucleate cells associated with the maternal epithelium syncytium and (c) binucleate cells of the chorionic membranes.
\end{abstract}

\section{Introduction}

It is now firmly established that lactogenic hormone(s) are elaborated by the placental tissue of primates and a large number of non-primate species (see Forsyth, 1974), and human and monkey placental lactogens have been purified (Friesen, 1965; Shome \& Friesen, 1971; Vinik, Kaplan \& Grumbach, 1973). A lactogenic hormone has been isolated from ovine placenta (Martal \& Djiane, 1975; Chan, Robertson \& Friesen, 1976; Fellows, Bolander, Hurley \& Handwerger, 1976; Reddy \& Watkins, 1978a, b). The immunohistochemical localization of placental lactogenic hormones has been studied primarily in human tissues (Watkins, 1978), but it has now been possible to localize ovine placental lactogen at the cellular level by using immunocytochemical techniques (Martal, Djiane \& Dubois, 1977; Reddy \& Watkins, 1978b). Martal et al. (1977) and Reddy \& Watkins (1978b) demonstrated that the hormone was predominantly present in the giant binucleate cells of the mature placenta. As an extension of our earlier work (Reddy \& Watkins, 1978b), the present study examines the ontogeny and distribution of the cells containing ovine placental lactogen.

\section{Materials and Methods}

Placental tissue was obtained from pregnant ewes at 22-145 days of gestation and prepared for histological examination as previously reported (Reddy \& Watkins, 1978b). Intercotyledonary placenta (chorionic membranes) was obtained from ewes at 110-120 days of pregnancy and prepared similarly. The gestational ages from 60 days onward were determined by radiological examination of the fetal hind limb (Lascelles, 1959) and checked by measurement of the crownto-rump length of the fetuses up to 100 days of gestation (Barcroft, 1952). Gestational ages of 40 days and less were determined from the day of mating. 
Preparation of rabbit anti-ovine placental lactogen serum and its use in the indirect immunofluorescence procedure was carried out as previously reported (Reddy \& Watkins, 1978b) with the modification that the primary antiserum was allowed to react for $12 \mathrm{~h}$ at $37^{\circ} \mathrm{C}$ with tissues collected from 22-day-pregnant ewes. The immunoperoxidase technique was performed as previously described by Watkins (1978), using the anti-ovine placental lactogen serum at a dilution of $1: 100$. After staining the sections for immunofluorescence, they were counterstained with the periodic acid-Schiff (PAS) reagent (Lillie, 1965). Boshier (1969) has previously shown that the PAS-positive binucleate cells are diastase-resistant.

\section{Observations}

The main histological features of the 22-, 40-, 80-, 100- and 145-day placentae are represented in Pl. 1, Fig. 1 and Pl. 2, Figs 3-6. In the Day-22 ovine placenta, the trophoblast consists of a thin membranous structure possessing numerous well-developed giant cells. These binucleate cells have also been detected in the trophoblast as early as Day 16 (Boshier, 1969). By Day 40, the fetal trophoblast shows the characteristic interdigitation with the placental tissue of maternal origin, with the maternal septum having an outer syncytial lining. As pregnancy proceeds, the thickness of the maternal septum and of the mesenchymal core of the fetal villi is progressively reduced.

Immunocytochemical localization of lactogen was demonstrated in placental tissue from pregnant ewes as early as 22 days of gestation (PI. 1, Fig. 2), but the intensity of the immunofluorescence was weak and appeared in only a few scattered cells. By 80-100 days gestation, the number of lactogen-containing cells had markedly increased with the presence of binucleate cells in the fetal trophoblast (Pl. 3, Figs 7 and 9) and uninucleate cells in the maternal epithelium syncytium (Pl. 4, Fig. 11). Subsequent PAS staining of the sections used for the immunofluorescence histology revealed that not all the PAS-positive cells stained for ovine placental lactogen (compare P1. 3, Figs 7 and 8 with Figs 9 and 10).

That the lactogen-positive giant cells were also present in the intercotyledonary chorion is shown in Pl. 4, Fig. 12. As in the case of the cotyledonary tissue, there was a discrepancy between the staining pattern of the placental lactogen-containing and the PAS-positive cells (Pl. 4, Fig. 13).

\section{Discussion}

At the light microscope level, Boshier (1969) showed that the binucleate cells first appear within the fetal trophoblast at about Day 16 of pregnancy. This timing is close to the time of 22 days at which we first observed the presence of binucleate cells containing ovine placental lactogen and at which Martal \& Djiane (1977) first detected low levels of ovine placental lactogen in extracts of the trophoblast by using a radioreceptor assay. By Day 48, Chan et al. (1978) were able to measure placental lactogen in the maternal serum by radioimmunoassay: maximum peripheral concentrations of ovine placental lactogen were recorded between 131 and 141 days of gestation, and then the levels declined just before parturition. Similar results were reported by Handwerger et al. (1977). At 145 days of gestation, it was found that, in general, the staining intensity of placental lactogen was less than that seen in the binucleate cells between Days 100 and 140. This suggests that the endocrine activity of the giant cells at this time may be reduced and perhaps accounts for the lower serum levels of placental lactogen at parturition.

Early electron microscope studies of the ontogenesis of the binucleate cells have led various workers to suggest that there is a migration of these cells from the fetal to the maternal syncytium (Wimsatt, 1951; Amoroso, 1952) from the 17th day of gestation and throughout 


\section{PLATE 1}
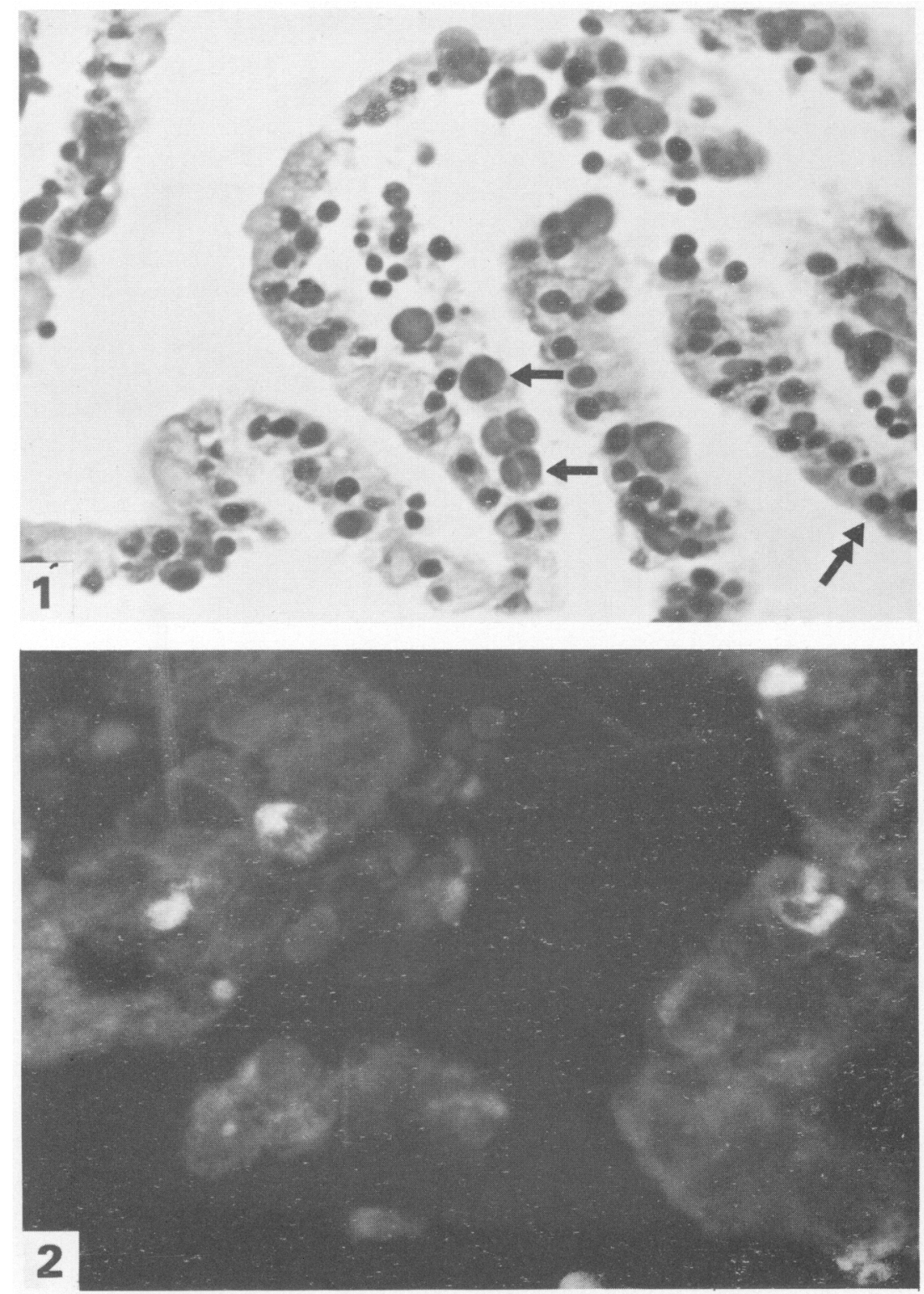

Sections of trophoblast taken from a ewe at 22 days of gestation.

Fig. 1. Stained with haematoxylin and eosin. The single arrows indicate the binucleate cells, double arrow uninucleate cells. $\times 563$.

Fig. 2. Stained by the immunofluorescence method with anti-ovine placental lactogen serum. $\times 770$. 

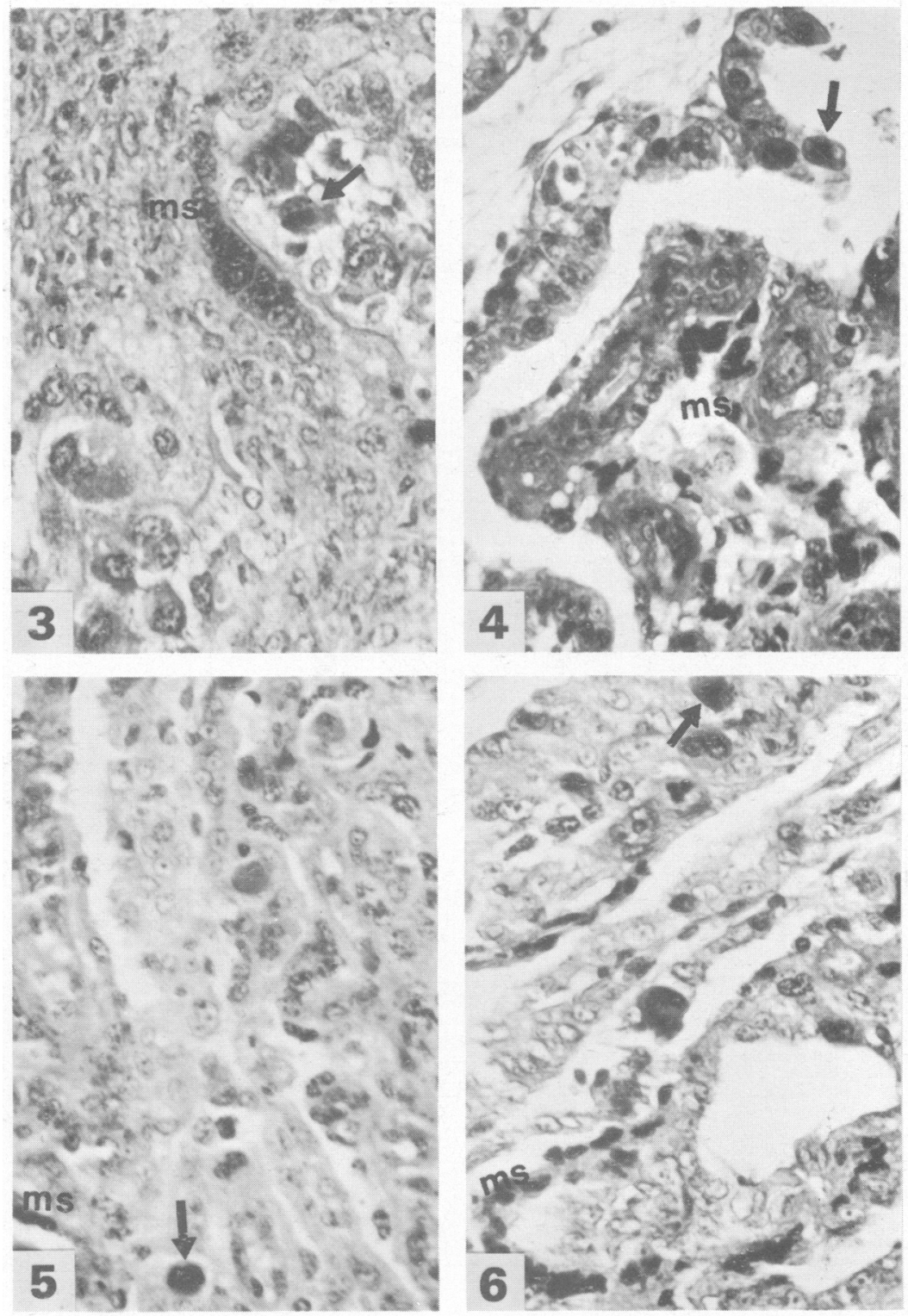

Figs 3-6. Sections from sheep placenta at Day 40 (Fig. 3), 80 (Fig. 4), 100 (Fig. 5) and 145 (Fig. 6) of gestation. Giant (binucleate) cells are arrowed; ms, maternal syncytium. $\times 352$. 


\section{PLATE 3}
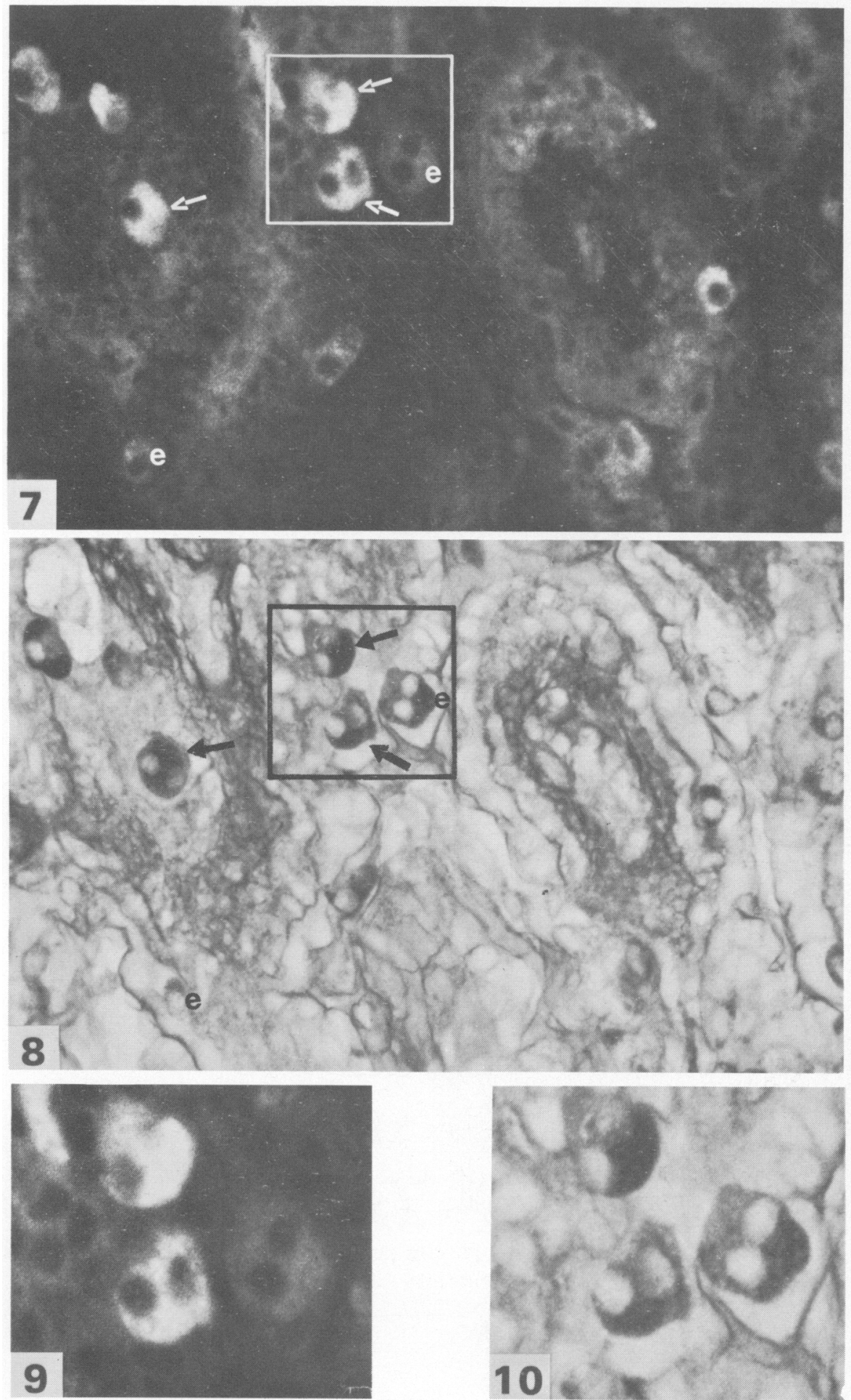

Fig. 7. Immunofluorescence localization of ovine placental lactogen in the binucleate cells (arrows) of the 100-day sheep placenta. The cells marked (e) are lactogen-negative giant cells. $\times 368$.

Fig. 8. The same section as in Fig. 7 but counterstained for PAS-positive material. $\times 368$.

Fig. 9. Area within square in Fig. 7. $\times 768$.

Fig. 10. Area within square in Fig. $8 . \times 768$. 

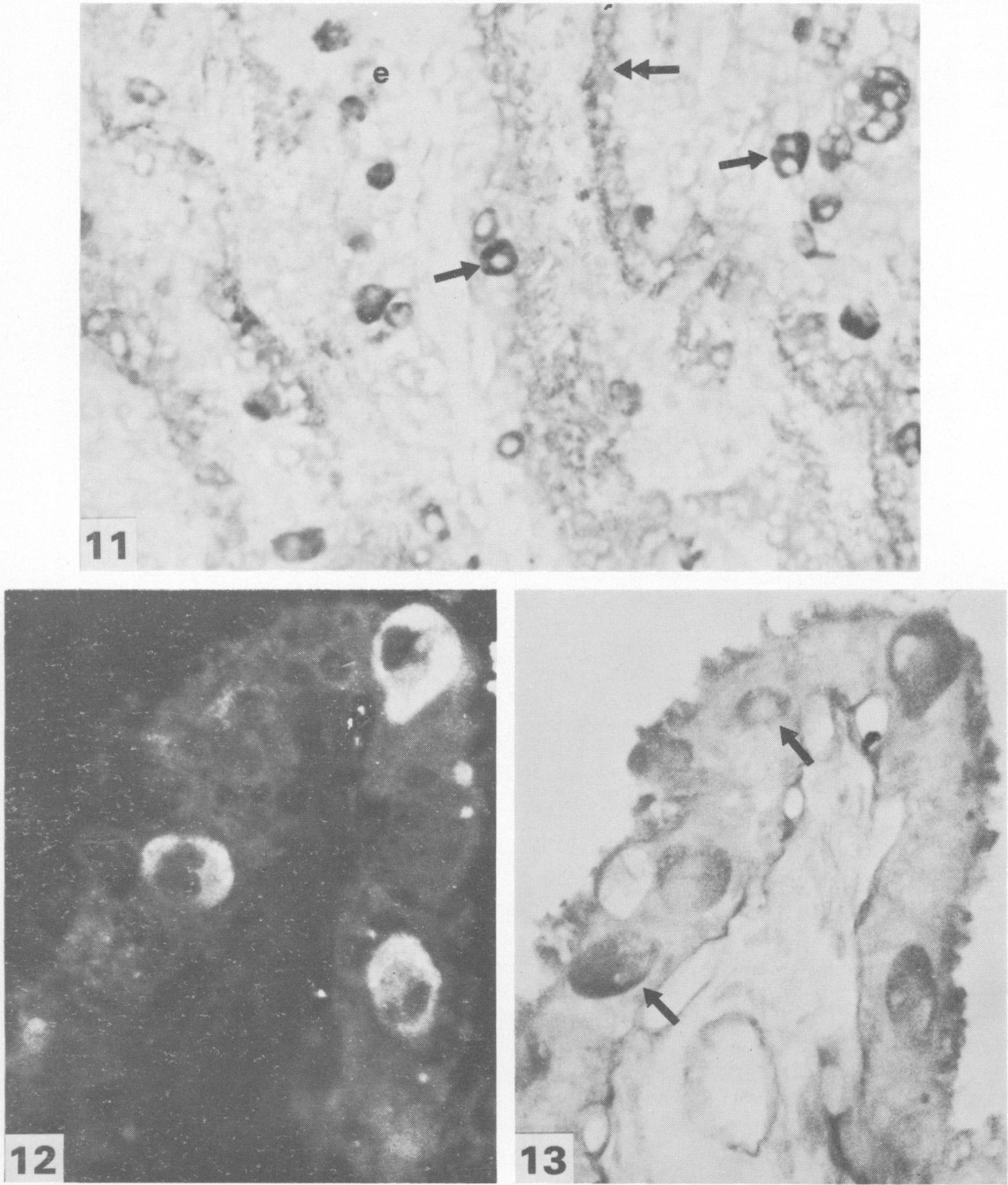

Fig. 11. Localization of ovine placental lactogen in the placenta of a sheep at 100 days of gestation. The immunoperoxidase method shows the lactogen in binucleate cells (single arrows) and uninucleate cells (double arrows). $\times 309$.

Fig. 12. Immunofluorescence localization of ovine placental lactogen in the binucleate cells of the chorionic membranes. $\times 690$.

Fig. 13. Same section as in Fig. 12 but re-stained with PAS reagent. The cells arrowed stained positively for PAS but negatively or only slightly, for lactogen. $\times 690$. 
pregnancy. This concept of binucleate cell migration has been supported by Steven (1977) and Steven et al. (1978). Steven et al. (1978) presented evidence to indicate that after fetal pituitary stalk section there was an enhanced migration of the giant cells towards the fetal-maternal interface and the movement was not suppressed by infusion of the fetus with cortisol or adrenocorticotrophin. Our observation that ovine placental lactogen is present in binucleate and uninucleate cells of the trophoblast (Reddy \& Watkins, 1978b) must be modified in the light of the present study. We now consider that the uninucleate placental lactogen-containing cells are localized within the maternal syncytium (D. H. Steven, personal communication) and that their immunofluorescence represents either the products of migration of lactogen-containing binucleate cells across the fetal-maternal interface or products of synthesis within the syncytium itself.

Little information is available on the significance of extraplacental membranes during pregnancy. Of the various substances present in human amniotic fluid (lecithin, sphingomyelin, chorionic gonadotrophin, prolactin, growth hormone, oestrogens, progesterone and prostaglandins (see Dawood, 1977), only prolactin has been found localized in cells of the amnion (Healy, Muller \& Burger, 1977) and capable of being released in vitro (Friesen et al., 1972). That ovine placental lactogen-containing binucleate cells are also present in the intercotyledonary placenta may again represent (a) products of local synthesis or (b) extensive migration of the binucleate cells originating from the fetal cotyledonary tissue. A possible role for chorionic ovine placental lactogen may be that proposed by Thorburn (1978), i.e. that the lactogen may be the putative factor which inhibits prostaglandin $F$ synthesis in the intercotyledonary endometrium (Louis, Parry, Robinson \& Challis, 1977), thereby controlling the onset of parturition.

Since not all cells that stain positively with PAS reagent contain ovine placental lactogen, caution must be exercised in interpreting the physiological role of placental lactogen solely on histochemical or electron microscopic examination. Clearly, the presence of binucleate cells does not necessarily reflect the presence of ovine placental lactogen. The apparent lack of placental lactogen in some giant cells may represent the immaturity of these cells with respect to the synthesis of the lactogen, but it is unlikely that they represent cells whose lactogen has been discharged into extracellular spaces, since one would also expect loss of the PAS-staining material. Alternatively, two classes of binucleate cells may exist in the placenta, one associated with the production of ovine placental lactogen and the other with the synthesis of another class of biologically active protein or steroid. Boshier \& Holloway (1977) have identified 2 types of binucleate cells at the ultrastructural level; one type was considered responsible for the synthesis of glycoprotein secretory material and the other with glycogen storage. We now propose the existence of another type of binucleate cell, i.e. one that is ovine placental lactogen-negative and PAS-positive. It still remains to be determined, however, whether ovine placental lactogen can be localized ultrastructurally with immunoperoxidase methods in a number of different cell types. Likewise, the role of the placental lactogen-positive and PAS-staining binucleate cells in the reproductive physiology of the ewe requires further examination.

This work was financed by The Medical Research Council of New Zealand. We thank the Ruakura Animal Research Centre, Hamilton, and Professor D. P. Boshier for assistance in the collection of placental tissue; and Professor D. P. Boshier and Dr D. H. Steven for helpful discussions.

\section{References}

Amoroso, E.C. (1952) Placentation. In Marshall's Physiology of Reproduction, 3rd edn, Vol. 2, pp. 127-311. Ed A.S. Parkes. Longmans Green, London.
Barcroft, J. (1952) Foetal respiration and circulation. In Marshall's Physiology of Reproduction, 3rd edn, Vol. 2, pp. 399-441. Ed. A. S. Parkes. Longmans Green, London. 
Boshier, D.P. (1969) A histological and histochemical examination of implantation and early placentome formation in sheep. J. Reprod. Fert. 19, 51-61.

Boshier, D.P. \& Holloway, H. (1977) The sheep trophoblast and placental function: an ultrastructural study. J. Anat. 124, 287-298.

Chan, J.S.D., Robertson, H.A. \& Friesen, H.G. (1976) The purification and characterization of ovine placental lactogen. Endocrinology 98, 65-76.

Chan, J.S.D., Robertson, H.A. \& Friesen, H.G. (1978) Maternal and fetal concentrations of ovine placental lactogen measured by radioimmunoassay. Endocrinology 103, 1606-1613.

Dawood, M.Y. (1977) Hormones in amniotic fluid. Am. J. Obstet. Gynec. 128, 576-583.

Fellows, R.E., Bolander, F.F., Hurley, T.W. \& Handwerger, S. (1976) Isolation and characterization of bovine and ovine placental lactogen. In Growth Hormone and Related Peptides, pp. 315-325. Eds A. Pecile \& E. E. Muller. Excerpta Medica, Amsterdam.

Forsyth, I.A. (1974) The comparative study of placental lactogenic hormones: a review. In Lactogenic Hormones, Fetal Nutrition and Lactation, pp. 49-67. Eds J. B. Josimovich, M. Reynolds \& E. Cobo. John Wiley and Sons, New York.

Friesen, H.G. (1965) Purification of a placental factor with immunological and chemical similarities to human growth hormone. Endocrinology 76, 369381.

Friesen, H., Hwang, P., Guyda, H., Tolis, G., Tyson, J. \& Myers, R. (1972) A radioimmunoassay for human prolactin. In Prolactin and Carcinogenesis, pp. 64-80. Eds A. R. Boyns \& K. Griffiths. Alpha Omega Alpha Publishing, Cardiff.

Handwerger, S., Crenshaw, C., Jr, Maurer, W.F., Barrett, J., Hurley, T.W., Golander, A. \& Fellows, R.E. (1977) Studies on ovine placental lactogen secretion by homologous radioimmunoassay. $J$. Endocr. 72, 27-34.

Healy, D.L., Muller, H.K. \& Burger, H.G. (1977) Immunofluorescence shows localization of prolactin to human amnion. Nature, Lond. 265, 642-643.

Lascelles, A.K. (1959) The time of appearance of ossification centres in the peppin-type merino. Aust. J. Zool. 7, 79-86.

Lillie, R.D. (1965) Histopathologic Technic and Practical Histochemistry, 3rd edn, pp. 198-199. McGraw-Hill Co., New York.
Louis, T.M., Parry, D.M., Robinson, J.S., Thorburn, G.D. \& Challis, J.R.G. (1977) Effects of exogenous progesterone and oestradiol on prostaglandin $F$ and 13,14-dihydro-15-oxo prostaglandin $F_{2 \alpha}$ concentrations in uteri and plasma of ovariectomized ewes. J. Endocr. 73, 427-439.

Martal, J. \& Djiane, J. (1975) Purification of a lactogenic hormone in sheep placenta. Biochem. Biophys. Res. Commun. 65, 770-778.

Martal, J. \& Djiane, J. (1977) The production of chorionic somatomammotrophin in sheep. J. Reprod. Fert. 49, 285-289.

Martal, J., Djiane, J. \& Dubois, M.P. (1977) Immunofluorescent localization of ovine placental lactogen. Cell Tiss. Res. 184, 427-433.

Reddy, S. \& Watkins, W.B. (1978a) Purification and some properties of ovine placental lactogen. $J$. Endocr. 78, 59-69.

Reddy, S. \& Watkins, W.B. (1978b) Immunofluorescence localization of ovine placental lactogen. $J$. Reprod. Fert. 52, 173-174.

Shome, B. \& Friesen, H.G. (1971) Purification and characterization of monkey placental lactogen. Endocrinology 89, 631-641.

Steven, D.H. (1977) Ultrastructure of the sheep placenta. In The Fetus and Birth (Ciba Fdn Symp. 47), pp. 99-105. Eds J. Knight \& M. O'Connor. Excerpta Medica, Amsterdam.

Steven, D.H., Bass, F., Jansen, C.J.M., Krane, E.J., Mallon, K., Samuel, C.A., Thomas, A.L. \& Nathanielsz, P.W. (1978) Ultrastructural changes in the placenta of the ewe after fetal pituitary stalk section. Q. Rev. Physiol. 63, 221-229.

Thorburn, G.D. (1978) Hormonal control of parturition in the sheep and goat. Seminars in Perinat. 2, 235245.

Vinik, A.I., Kaplan, S.L. \& Grumbach, M.M. (1973) Purification, characterization and comparison of immunological properties of monkey chorionic somatomammotrophin and ovine prolactin. Endocrinology 92, 1051-1064.

Watkins, W.B. (1978) Use of immunocytochemical techniques for the localization of human placental lactogen. J. Histochem. Cytochem. 26, 288-292.

Wimsatt, W.A. (1951) Observations on the morphogenesis, cytochemistry and significance of the binucleate giant cells of the placenta of ruminants. Am. J. Anat. 89, 233-282. 